\title{
IN VITRO RUMINAL AND POST-RUMINAL PROTEIN DEGRADATION OF UNTREATED AND TREATED SOYBEAN MEAL
}

\author{
Marwa F.A. Attia, M.E. A. Nasser, K.A. El-Shazly and S. M.A. Sallam* \\ ${ }^{2}$ Department of Animal and Fish and Production, Faculty of Agriculture, University of Alexandria, \\ Egypt \\ *Corresponding author: Prof. Dr. Sobhy M.A. Sallam, Department of Animal and Fish Production, \\ Faculty of Agriculture, University of Alexandria, El-Shatby, Alexandria, Egypt Tel., +203-5921863 - \\ Fax: +203-5922780 - E mail: (s_sallam@yahoo.com)
}

(Received 15/2/2016, accepted 30/3/2016)

\section{SUMMARY}

$\mathrm{T}$ his study was designed to determine the characteristics of rumen fermentation, and post-ruminal protein digestion of untreated and treated soybean meal (SBM) using gas production (GP) technique and three step in situ/in vitro procedures. Soybean meal (SBM) was treated by autoclaving, roasting, with ethanol and mixed by various proportions of Acacia saligna (AS) leaves (1:3, 1:1, $3: 1)$ ratios. The results showed that the highest cumulative GP was observed in untreated SBM followed by treated SBM with ethanol, roasted SBM and SBM+AS (3:1). The lowest mean values of GP were obtained in SBM+AS (1:3), autoclaved SBM and SBM+AS (1:1). The predicted metabolizable energy (ME, MJ/kg DM) and net energy (NE, MJ/kg DM) varied widely in substrates and was particularly high in untreated SBM, while SBM+AS (1:3) had significantly the lowest values of ME and NE. The highest mean values of $\mathrm{NH}_{3}-\mathrm{N}$ concentration were obtained with untreated SBM, while the lowest was obtained with autoclaved SBMand followed by SBM+AS (1:3), ethanol-treated SBM and roasted SBM. Rumen degradable protein (RDP, \%) varied from $33.6 \%$ in autoclaving SBM to $62.4 \%$ in SBM+AS (3:1). Intestinal protein digestion (IPD, \%) content was highest in autoclaving-SBM, roasting SBM and untreated SBM and lowest mean value of IPD was recorded in SBM+AS $(1: 1)$.The highest mean values for VFA concentrations were obtained with $\mathrm{SBM}+\mathrm{AS}$ (3:1)and SBM treated with ethanol followed by SBM plus A. saligna leaves (1:3). The lowest mean value of VFA concentration was obtained by autoclaving SBM or roasting SBM. It is concluded that autoclaving SBM, ethanol- treated SBM and mixing SBM with Acacia leaves (1:3) could be used advantageously to reduce RDP and increase the bypass protein but the autoclaving SBM showed the best treatment on improving the intestinal protein digestion of SBM.

Key words: Intestinal digestion, heating, gas production, in vitro

\section{INTRODUCTION}

The value of any protein to ruminant animals depends on the efficiency with which both the fraction that is degraded in the rumen and built into microbial protein, and that which is undegraded, are dealt with by the intestinal tract subsequent to leaving the rumen, and in particular how the protein is digested in the small intestine of ruminant. In addition, the benefit of any feed protein to ruminants depends on how the protein is digested in the small intestine (Calsamiglia and Stern, 1995; McNiven et al., 2002). There was a wide variation in ruminal and post-ruminal protein disappearance of the feeds evaluated by different insitu and invitro digestibility methods. Grains, by-products and protein sources are more susceptible for digestion in the ruminant gastrointestinal tract than forages and halophytes (Danesh Mesgaran and Stern, 2005).

Proteins of soybean meal (SBM), which is a commonly used protein supplement for ruminants, are extensively degraded in the rumen. It is very palatable and has a good amino acid balance and high availability. It is estimated that only 34\% SBM protein escape rumen fermentation. Therefore, improvement in ruminal escape characteristics of SBM is of major importance to both beef and dairy producers and the soybean industry. Some attempts to decrease the extent of ruminal degradation of SBM proteins have used treatment with dry or moisture heat (Nakamura et al., 1994), ethanol (Corley et a.,. 
1999), formaldehyde (Mir et al., 1984), tannic acid and quebracho (El-Waziryet al., 2005, 2007), acetic acid (Robinson et al., 1994), and xylose (Harstad and PrestlØkken, 2000).

Accurate estimation of ruminal and intestinal protein disappearance of feed is also essential for ruminant diet formulation. The mobile bag technique, using duodenallycannulated cows, provides an estimation of total tract protein disappearance and correlates well with true intestinal nitrogen digestibility in vivo (Hvelplundet al., 1994). However, the cost and unpredictability of surgically modifying a number of steers or cows, as well as animal welfare issues, have led the nutritionist to investigate laboratory methods to estimate ruminal and postruminal protein disappearance (Calsamiglia and Stern, 1995; McNivenet al., 2002; Tejidoet al., 2002). Numerous laboratory methods are currently used for estimating ruminal and intestinal disappearance of feed protein using various enzymatic procedures (Calsamiglia and Stern, 1995; McNivenet al., 2002). These methods are simple to conduct and reasonable in cost, compared with the in vivo method. In addition, they yield values that are estimates of true digestibility of feed protein. Invitro gas production method has been shown to be well correlated with invivo results (Cone et al., 2006), and it is sensitive to the presence of compounds that reduce intestinal protein utilization (Calsamiglia and Stern, 1995). Voluntary intake of a feed depends essentially on the rate of ruminal and post-ruminal digestion of digestible nutrients (Ørskovet al., 1988); especially CP as an index for feed digestion potential. Therefore, in order to define an optimum ruminant diet in a tropical area, it is necessary to choose feedstuffs according to the quantity and quality of available CP. Therefore, the aim of this experiment was to study the effect of some treatments (roasting, autoclaving or ethanol) of SBM and mixing SBM with Acacia saligna leaves with different proportions of tannins content gas production, kinetics of gas production, ruminal fermentation, dry and organic matter degradation, ruminal and intestinal protein digestion using gas production technique and three-step in situ/in vitro procedures.

\section{MATERIALS AND METHODS}

The present study was carried out at the Rumen Microbiology Laboratory, Department of Animal Production, Faculty of Agriculture, Alexandria University, Egypt.

\section{Animals and diet}

Three rumen cannulated sheep were used as source of rumen inoculum and for three step in situ/in vitro technique. The animals were fed on commercial concentrate mixture and rice straw throughout the experiment period.

\section{Experimental feeds and treatments}

Feed samples included untreated SBM in comparison with treated SBM and associative effect of mixing SBM with A. saligna leaves in various proportions. The treatments were as follow:

1) Untreated SBM.

2) Treated SBM with $70 \%$ Ethanol (Sadeghi and Shawrang, 2007).

3) Roasting SBM at $155^{\circ} \mathrm{C}$ for 30 min (Nowak et al., 2005).

4) Autoclaving SBM at $121^{\circ} \mathrm{C}$ for $30 \mathrm{~min}$ (Broderick and Craig, 1980).

5) $\mathrm{SBM}+$ Acacia saligna leaves $(3: 1)$.

6) $\mathrm{SBM}+$ Acacia saligna leaves $(1: 1)$.

7) $\mathrm{SBM}+$ Acacia saligna leaves (1:3).

\section{Chemical analyses}

All feed samples were dried using a forced-air oven at $50^{\circ} \mathrm{C}$ for $48 \mathrm{~h}$. The feed samples were ground to pass through a $1-\mathrm{mm}$ screen and analyzed for DM; dry matter-ID number 930.15; OM: organic matterID number 942.05; CP: crude protein - as 6.25 x N- ID number 954.01 (AOAC, 1995) and ADF; acid detergent fibre - ID number (973.18) and NDF: neutral-detergent fibre, (Mertens, 2002). Untreated and treated SBM were also analyzed for extractable total phenols (TP), tannins (TT) and condensed tannins (CT). Dried plant material (200 mg) was extracted with acetone: water (10 ml, 70:30 v/v) in an ultrasonic bath for 20 minutes. The contents were centrifuged $\left(4^{\circ} \mathrm{C}, 10 \mathrm{~min}, 3000 \mathrm{~g}\right)$ and the supernatant was kept on ice until analysis. Total phenols were determined with the Folin-Ciocalteau reagent (Makkaret al., 1993, Makkar, 2003). Extractable tannins were determined as the difference in total phenols (measured by Folin-Ciocalteau reagent) before and after treatment with insoluble polyvinyl polypyrrolidone (PVPP), as this polymer binds strongly to tannins (Makkaret al., 1995). TP and TT were expressed as tannic acid 
equivalents. Condensed tannins were measured by the $\mathrm{HCl}$-butanol method and the results were expressed as leucocyanidin equivalent (Makkar, 2003).

\section{In vitro gas production technique}

In vitro gas production was undertaken according to the procedure described by Menke and Steingass (1988). Samples $(100 \mathrm{mg})$ of the air-dry feedstuffs were accurately weighted into $50 \mathrm{ml}$ calibrated glass syringe fitted with plungers. The buffer solution used for in vitro gas production was defined as MB9 (Onodera and Handerson, 1980). Then the buffer $\mathrm{pH}$ was adjusted at 6.8 and $\mathrm{CO}_{2}$ flushed for 30 min. Rumen contents (50\% solid: $50 \%$ liquid) were collected from three rumen cannulated sheep which was fed with rice straw ad lib and commercial concentrate mixture. The rumen contents were collected before the morning feeding of the animals. Liquids and solids were placed in pre-warmed $\left(39^{\circ} \mathrm{C}\right)$ insulated flasks and transported under anaerobic conditions to the laboratory. The rumen contents were squeezed through four layers of cheese-cloth and kept in a water bath at $39^{\circ} \mathrm{C}$ with $\mathrm{CO}_{2}$ saturation until inoculation took place. The buffer and inoculum $(2: 1 \mathrm{v} / \mathrm{v})$ were mixed and kept in a water bath at $39^{\circ} \mathrm{C}$ with $\mathrm{CO}_{2}$ saturation (Solivaet al., 2005).

Buffered rumen fluid $(15 \mathrm{ml})$ was pipetted into each syringe, containing the feed samples, and the syringes were immediately placed into the water bath at $39^{\circ} \mathrm{C}$. Syringes were incubated in vitro in water bath for $96 \mathrm{~h}$ and gently shaken every $2 \mathrm{~h}$. Half of the syringes were terminated after $24 \mathrm{~h}$ incubation for determination of the ammonia- $\mathrm{N}\left(\mathrm{NH}_{3}-\mathrm{N}\right)$, volatile fatty acids (VFA) and truly degraded dry and organic matter. The rest of the syringes were continuously incubated up to $96 \mathrm{~h}$ and gas production was recorded at $3,6,9,12,24,72$ and $96 \mathrm{~h}$ of incubation in vitro.

Three runs were performed for each experiment consisting of four syringes containing only buffered rumen fluid considered as the blank, four syringes for each sample and four syringes for Berseem hay as a high quality roughage and internal standard to correct the variation between runs. The gas values were expressed as $\mathrm{ml}$ per $200 \mathrm{mg}$ of DM (remember only 100mg was incubated). The cumulative gas production $(\mathrm{Y})$ at time $(\mathrm{t})$ was fitted to the exponential model of (Ørskov and McDonald, 1979). Gas $(t)=$ $\mathrm{a}+\mathrm{b}^{*}(1-\exp -\mathrm{c} t), \mathrm{a}=$ the gas production from the soluble fraction $(\mathrm{ml}), \mathrm{b}=$ the gas production from the insoluble fraction $(\mathrm{ml}), \mathrm{c}=$ the gas production rate $(\mathrm{ml} / \mathrm{h}), \mathrm{t}=$ incubation time $(\mathrm{h})$.

\section{Rumen fermentation and degradation}

The content of the syringes at $24 \mathrm{~h}$ of incubation were transferred to the centrifuge tube and centrifuged at $3000 \mathrm{~g}$ for $10 \mathrm{~min}$. Five milliliter from the supernatant were transferred into $25 \mathrm{ml}$ glass bottle and stored in a freezer until they were analyzed for $\mathrm{NH}_{3}-\mathrm{N}$ and VFA determination. Volatile fatty acids and ammonia concentration were determined according to Warner, (1964) and Preston, (1995), respectively. True dry and organic matter digestibility were determined for the half of the syringes at $24 \mathrm{~h}$ incubation according to the procedure described by Van Soest, (1994) incubating the syringe residue with neutral detergent solution (NDS) at $110^{\circ} \mathrm{C}$ for $3 \mathrm{~h}$ (the purpose of this treatment is to solubilize the microbes and to only obtain the undegraded feed). The contents were filtered through crucibles; the residue was washed with distilled water then with acetone. The crucibles were dried at $110^{\circ} \mathrm{C}$ for $24 \mathrm{~h}$ for determining truly dry matter degradation. Then the crucibles were transferred to a muffle furnace for $2 \mathrm{~h}$ at $600^{\circ} \mathrm{C}$ for determining truly organic matter degradation.

\section{Predicted parameters}

A new approach to evaluate feeds from gas parameters was adopted where, gas production from fermentation of the soluble fraction (GPSF) was estimated from gas produced after $3 \mathrm{~h}$ (GP3) of incubation. Gas production from fermentation of the insoluble fraction (GPNSF) was estimated from the gas production between $3 \mathrm{~h}$ (GP3) and $24 \mathrm{~h}$ (GP24) of incubation according to Van Gelderet al. (2005). The energy values were calculated from the amount of gas produced at $24 \mathrm{~h}$ of incubation with supplementary analyses of crude protein, ash and crude fat. This approach was developed by the research group in Hohenheim (Germany) and is based upon extensive in vitro incubation of feedstuffs (Menkeet al., 1979; Menke and Steingass, 1988).

$$
\begin{aligned}
& \mathrm{ME}(\mathrm{MJ} / \mathrm{kg} \mathrm{DM})=1.06+0.157 \mathrm{GP}+0.084 \mathrm{CP}+0.22 \mathrm{EE}-0.081 * \mathrm{~A} \\
& \mathrm{OMD}(\%)=14.88+0.889 \mathrm{GP}+0.45 \mathrm{CP}+0.0651 * \mathrm{~A}
\end{aligned}
$$

Where: ME is the metabolizable energy, OMD is organic matter digestibility, GP is $24 \mathrm{~h}$ net gas production (ml/200 $\mathrm{mg} \mathrm{DM}), \mathrm{CP}$ is crude protein (\% of DM), A is ash (\% of DM)

$\mathrm{NE}(\mathrm{Mcal} / \mathrm{lb})=(2.2+(0.0272 * \mathrm{Gas})+(0.057 * \mathrm{CP})+(0.149 * \mathrm{EE})) / 14.64$ 
Where: NE is the net energy, Gas is $24 \mathrm{~h}$ net gas production $(\mathrm{ml} / \mathrm{g} \mathrm{DM}), \mathrm{CP}$ is crude protein (\% of DM), EE is ether extract (\% of DM)

\section{Three-step procedure in situ/ in vitro}

Ruminal and post-ruminal protein digestion of the various treatment feeds or diets were evaluated using and three-step insitu/invitro procedure (Calsamiglia and Stern, 1995). This part of the experiment followed the procedure of Calsamiglia and Stern (1995). Approximately, (4.0 g) of feed sample were weighed into a $6 \mathrm{~cm} \times 10 \mathrm{~cm}$ Dacron polyester bag with a pore size of $52 \mu \mathrm{m}$ (four bags per sample) and suspended in the rumen of a cannulated sheep for $16 \mathrm{~h}$. Bags were then removed and washed with cold tap water using a washing machine, frozen for $48 \mathrm{~h}$ and later washed and dried in a forced-air oven at $55^{\circ} \mathrm{C}$ for $48 \mathrm{~h}$ and weighed. Samples from each bag were taken for $\mathrm{N}$ analysis using the Kjeldahl method. Samples of ruminal undegraded residue $(0.5 \mathrm{~g})$ were weighed into a $50 \mathrm{ml}$ polypropylene centrifuge tube. Two blank tubes were also prepared to correct for $\mathrm{N}$ contribution of the enzymes. Ten milliliters of prewarmed $\left(37^{\circ} \mathrm{C}\right) \mathrm{HCl}$-pepsin solution (1 g of pepsin (Sigma P-7012) dissolved into 11 of $\left.0.1 \mathrm{~N} \mathrm{HCl}\right)$ were added into each tube. Tubes were vortexed and incubated for $1 \mathrm{~h}$ in a shaking water bath at $39^{\circ} \mathrm{C}$. After the $1 \mathrm{~h}$ incubation, $0.5 \mathrm{ml}$ of $1 \mathrm{~N} \mathrm{NaOH}$ solution was added and tubes were again vortexed. The procedure continued by adding $13.5 \mathrm{ml}$ of phosphate-pancreatin buffer $\left(0.5 M \mathrm{KH}_{2} \mathrm{PO}_{4}\right.$ buffer standardized at pH 7.8 containing $50 \mathrm{ppm}$ of thymol and $3 \mathrm{~g} / \mathrm{L}$ of pancreatin (Sigma 7545). Tubes were vortexed and incubated for $24 \mathrm{~h}$ in a shaking water bath at $39^{\circ} \mathrm{C}$. After incubation, $3 \mathrm{ml}$ of trichloro actetic acid (TCA, 100\%) solution were added to each tube, then vortexed. The tubes were left for 15 min and then centrifuged at $10,000 \times \mathrm{g}$ for $15 \mathrm{~min}$. Part of the supernatant $(5 \mathrm{ml})$ was pipetted from each tube for $\mathrm{N}$ concentration determination by the Kjeldahl method .

\section{Statistical analysis}

Data were analyzed by the generalized linear model procedure in SAS (2002). The following model was assumed: $Y_{i j}=\mu+F_{i}+e_{i j}$. Where: $\mu$ is the overall mean, $F_{i}$ is the treatment diets, $e_{i j}$ is the random error term. Gas production runs were considered as the experimental units. Each run was repeated three times, and replicates within the same run were considered as repetitions. Differences among means were tested using Duncan multiple range test (Steel and Torrie, 1980).

\section{RESULTS AND DISCUSSION}

The mean values of the proximate analysis and tannin content on dry matter basis of the untreated SBM, treated SBM and mixed SBM with A. saligna leaves are presented in Table (1). Ash content did not significantlydiffer among treatment diets. Crude protein (CP) ranged from $25.1 \%$ in SBM+AS (1:3) to $44.6 \%$ in SBM. Ether extract content ranged from 1.9\% in SBM+AS (3:1) to $4.2 \%$ in treated SBM with ethanol. The fiber fractions did not significantlydiffer between untreated or treated SBM. The highest value for NDF and ADF were observed in SBM+AS (1:3), SBM+AS (1:1) and SBM+AS (3:1) but did not differ significantly among untreated SBM, roasted SBM, treated SBM with ethanoland autoclaving SBM respectively. The highest value for TP, TT and CT were observed in SBM+AS (1:3) and SBM+AS $(1: 1)$.

Table (1). Proximate analyses and tannins content of the treated, untreated SBM and mixed SBM with Acaciasaligna (AS) leaves (DM Basis)

\begin{tabular}{lcccccccc}
\hline Item & CP & EE & Ash & NDF & ADF & TP & TT & CT \\
\hline SBM & 44.6 & 2.0 & 6.6 & 19.0 & 12.9 & 0.19 & 0.12 & 0.03 \\
Ethanol-treated SBM & 43.8 & 4.2 & 5.6 & 20.9 & 14.6 & 0.43 & 0.14 & 0.11 \\
Roasting SBM & 44.2 & 2.2 & 6.2 & 19.8 & 12.7 & 0.12 & 0.03 & 0.13 \\
Autoclaving SBM & 44.4 & 2.2 & 5.8 & 19.5 & 11.7 & 0.36 & 0.04 & 0.09 \\
SBM+AS (3:1) & 37.28 & 1.9 & 6.9 & 23.6 & 18.3 & 0.43 & 0.32 & 0.65 \\
SBM+AS (1:1) & 30.8 & 3.9 & 7.6 & 28.2 & 23.5 & 1.12 & 0.62 & 1.56 \\
SBM+AS (1:3) & 25.1 & 2.5 & 8.7 & 35.1 & 33.8 & 2.85 & 2.00 & 1.86 \\
\hline SBM: Soybean meal, AS: Acacia saligna, CP: crude protein, EE: ether extract,NDF: neutral detergent fiber, ADF: \\
acid detergent fiber, TP: total phenols (eq-g tannic acid /100g DM), TT: total tannins (eq-g tannic acid /100g DM), \\
CT: condensed tannins (eq-g leucocyanidin/100g DM).
\end{tabular}


Figure (1) shows the cumulative gas production profiles, corrected for blank, for untreated, treated SBM and mixed SBM with A.saligna leaves incubated in buffered rumen fluid for $96 \mathrm{~h}$ in vitro. The highest cumulative gas production was observed in SBM followed by treated SBM with ethanol, roasting SBM and SBM+AS (3:1). On the other hand, roasting SBM and SBM+AS (3:1) did not differ significantly, while the lowest mean values was obtained by SBM+AS (1:3), autoclaving SBM and SBM+AS (1:1).
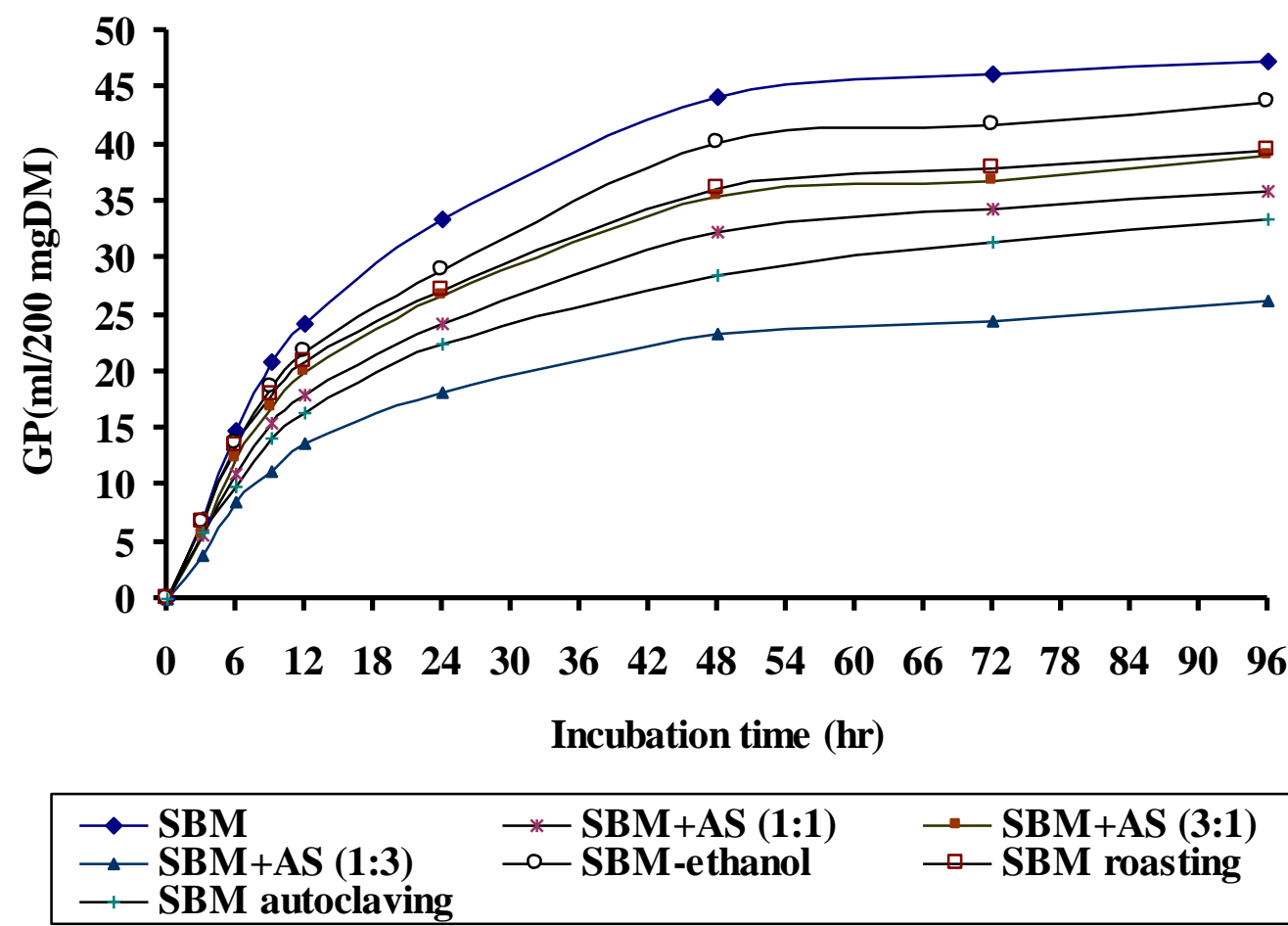

Figure (1). Cumulative gas production profiles for untreated and treated SBM and mixed SBM with Acacia saligna (AS) leaves incubated $96 \mathrm{~h}$ in vitro.

The least square means of the estimated parameters obtained from exponential model, GPSF and GPNSF (ml/ g DM) are given in Table 2. Estimated constant rate of gas production (c) did not significantlydiffer among untreated, treated SBM and mixed SBM with A. saligna leaves. The fitted $a+b$ values ranged from $25.3 \mathrm{inSBM}+\mathrm{AS}$ (1:3) to $47.0 \mathrm{ml}$ in SBM. There were wide variations among untreated, treated SBM and mixed SBM with A. saligna leaves in terms of GPSF and GPNSF. The results showed that SBM+AS (1:3) had the lowest GPSF and GPNSF followed by SBM+AS (1:1), SBM+AS (3:1) and autoclaving SBM. In concern of GPSF, there were no significant effects for roasting or ethanoltreated SBM in comparison to untreated SBM.

In the present study, heat treatment of SBM significantly $(\mathrm{P}<0.05)$ reduced the rapidly soluble fraction and the gas production rate. Similar results were reported by Konishiet al. (1999) who examined roasted $\mathrm{SBM}$ at 133,143 and $153^{\circ} \mathrm{C}$ for $3 \mathrm{~h}$ using nylon bag technique. Heating creates crosslinkages between peptide chains and, in the presence of carbohydrate, forms complexes between free amino and aldehyde groups through Maillard reaction. These reactions lower the protein solubility. Heat treatment of SBM is reported to reduce protein degradation in the rumen resulting from a lower solubility of protein in the rumen and these results are in agreement with the present study for decreasing soluble fraction (Table 2).

In the present study, heat treatment of SBM (autoclaving SBM) significantly $(\mathrm{P}<0.05)$ reduced the degradation constant ( $\mathrm{a}$ and $\mathrm{b}$ fractions) and the gas production rate (c). Similar results were reported by LjØkjelet al., (2000) who tested autocalved SBM at 120 and $130^{\circ} \mathrm{C}$ for $30 \mathrm{~min}$ using in situ technique. Also, heat treatment of SBM by expelling and roasting has shown the same effect (Titgemeyer and Shirley, 1997 and El-Waziryet al., 2005). Whenmixing SBM with A. saligna leaves in different proportions, the estimated parameters using gas production technique was significantly $(\mathrm{P}<0.05)$ decreased compared with untreated SBM. The beneficial effects of feeding tanniniferous plant species with protein-rich diet are generally described to the protection of proteins from degradation in the rumen due to the presence of small amounts of condensed tannins (CT) in the plant species. Condensed tannins 
are one of two distinct types of polymers of flavonoid phenols and as chemical additives for decreasing ruminal degradation of feed proteins were used to protect protein sources such as SBM. When tannincontaining plants are eaten, most binding appears to take place during chewing, but additional binding can occur in the rumen, including binding of proteins from other dietary components (Waghorn and Jones, 1989). There is concern that if tannin concentration in the diet becomes too high, microbial enzyme activities (Makkaret al., 1988) and intestinal digestion (Horigomeet al., 1988) may be depressed. Treated SBM with tannic acid or CT (Frutos et al., 2000; El-Waziryet al., 2005, 2007) decreased the degradation of SBM. Min et al. (2003) reported in their review that dietary concentrations of CT, ranging from 20 to $45 \mathrm{~g} / \mathrm{kg} \mathrm{DM}$, improved efficiency of $\mathrm{N}$ use and increased the daily weight gain in lambs on temperate fresh forages like Lotus corniculatus.

Table (2). Least square means $( \pm \mathrm{SE})$ of gas production kinetics for the treated and untreated SBM and mixed SBM with Acaciasaligna (AS) leaves incubated in vitro $96 \mathrm{~h}$.

\begin{tabular}{lcccc}
\hline Item & $\mathrm{a}+\mathrm{b}$ & $\mathrm{c}$ & GPSF & GPNSF \\
\hline SBM & $47.0 \pm 3.4^{\mathrm{a}}$ & $0.060 \pm 0.004$ & $31.6 \pm 4.4^{\mathrm{a}}$ & $136.2 \pm 8.3^{\mathrm{a}}$ \\
Ethanol-treated SBM & $43.1 \pm 3.7^{\mathrm{a}}$ & $0.054 \pm 0.005$ & $30.7 \pm 4.8^{\mathrm{a}}$ & $115.2 \pm 9.1^{\mathrm{ab}}$ \\
Roasting SBM & $38.5 \pm 3.4^{\mathrm{b}}$ & $0.061 \pm 0.004$ & $30.1 \pm 4.4^{\mathrm{a}}$ & $106.4 \pm 8.3^{\mathrm{b}}$ \\
Autoclaving SBM & $32.2 \pm 3.4^{\mathrm{bc}}$ & $0.061 \pm 0.004$ & $26.1 \pm 4.4^{\mathrm{ab}}$ & $86.8 \pm 8.3^{\mathrm{c}}$ \\
SBM+AS (1:1) & $35.1 \pm 3.4^{\mathrm{b}}$ & $0.057 \pm 0.004$ & $24.6 \pm 4.4^{\mathrm{b}}$ & $97.3 \pm 8.3^{\mathrm{b}}$ \\
SBM+AS (3:1) & $38.1 \pm 3.4^{\mathrm{b}}$ & $0.059 \pm 0.004$ & $24.9 \pm 4.4^{\mathrm{b}}$ & $109.2 \pm 8.3^{\mathrm{b}}$ \\
SBM+AS (1:3) & $25.3 \pm 3.4^{\mathrm{c}}$ & $0.061 \pm 0.004$ & $16.2 \pm 4.4^{\mathrm{c}}$ & $74.9 \pm 5.7^{\mathrm{d}}$ \\
\hline
\end{tabular}

Means within a column bearing different superscripts differ $(P<0.05)$

SBM: Soybean meal, AS: Acacia saligna, a: gas production from the soluble fraction ( $\mathrm{ml}), b$ : gas production from the insoluble fraction $(\mathrm{ml}), \mathrm{c}$ : gas production rate $(\mathrm{ml} / \mathrm{hr}), \mathrm{GPSF}$ : gas production from soluble fractions $(\mathrm{ml} / \mathrm{g} \mathrm{DM})$, GPNSF: gas production from non-soluble fractions ( $\mathrm{ml} / \mathrm{g} D M)$, SE: standard error.

Fukushima (1969) described the mechanism of protein denaturation by ethanol solutions. The addition of a solvent, such as ethanol, that is miscible with water but less polar, lowers the dielectric constant of the system. This tends to increase the strength of all electrostatic interactions between protein molecules in contact with water. The presence of the less polar solvent weakens the hydrophobic bonds inside the proteins. In this situation, the structure of the protein changes and, hence, it is denatured. Treatment of SBM with ethanol solutions decreased the washout fraction of CP. It is important to note that effects of heat and ethanol treatments on protein structures are different. Heat processing can result in protein denaturation and aggregation, formation of cross-linkages between amino acids and reducing sugars (i.e. the Maillard reaction), or between proteins (i.e. iso-peptide bonds). These two latest reactions will probably make the protein more resistant to degradation in the rumen and small intestine. In this study, ethanol treatments decreased intestinal digestibility of CP compared to untreated SBM. In native structure of globular proteins, many hydrophobic amino acids are buried inside the protein. Ethanol solution induces the unfolding of the protein and denaturation, thus exposing non-polar groups that were previously blocked (Taha and Mohamed, 2004). Ethanol processing of SBM exposed hydrophobic amino acids (especially aromatics) that are position groups for active site of pepsin and trypsin enzymes (Murray et al., 2003).

The least square means of metabolizable energy (ME, MJ/kg DM), net energy ( $\mathrm{NE}, \mathrm{MJ} / \mathrm{kg} \mathrm{DM}$ ), organic matter digestibility $(\mathrm{OMD} \%)$ and microbial protein $(\mathrm{MP}, \mathrm{g} / \mathrm{kg} \mathrm{DOM})$ from gas production and chemical analyses for untreated, treated SBM and mixed SBM with AS leaves are presented in Table (3). The predicted ME varied widely in substrates and was particularly high in SBM, while SBM+AS (1:3) had significantly lower values of ME and NE. Microbial protein content varied from $82.8 \mathrm{~g} / \mathrm{kg} \mathrm{DOM}$ inSBM+AS (1:3) to $125.4 \mathrm{~g} / \mathrm{kg}$ DOM in SBM. Roasting autoclaving and ethanol-treated SBM decreased energy content, OMD and MP while the differences were significant for ME and OMD in comparison with untreated SBM. There were negative associative effects on SBM in terms of SCFA, energy content, OMD and MP. The lowest values for the predicted parameter were recorded with SBM+AS (1:3). 
Table (3). Least square means for the predicted parameters from gas production and chemical analyses for untreated SBM, treated SBM and mixing SBM with Acacia saligna (AS) leaves by different proportions in vitro $( \pm \mathrm{SE})$.

\begin{tabular}{lcccc}
\hline Item & ME & NE & OMD & MP \\
\hline SBM & $9.29 \pm 0.32^{\mathrm{a}}$ & $5.98 \pm 0.21^{\mathrm{a}}$ & $65.0 \pm 2.1^{\mathrm{a}}$ & $125.4 \pm 4.1^{\mathrm{a}}$ \\
Ethanol-treated SBM & $8.66 \pm 0.35^{\mathrm{b}}$ & $5.79 \pm 0.23^{\mathrm{a}}$ & $60.7 \pm 2.3^{\mathrm{b}}$ & $117.2 \pm 4.5^{\mathrm{ab}}$ \\
Roasting SBM & $8.44 \pm 0.32^{\mathrm{b}}$ & $5.85 \pm 0.21^{\mathrm{a}}$ & $59.3 \pm 2.1^{\mathrm{b}}$ & $114.5 \pm 4.1^{\mathrm{ab}}$ \\
Autoclaving SBM & $7.81 \pm 0.32^{\mathrm{b}}$ & $5.35 \pm 0.21^{\mathrm{b}}$ & $55.2 \pm 2.1^{\mathrm{b}}$ & $106.6 \pm 4.1^{\mathrm{b}}$ \\
SBM+AS(1:1) & $7.47 \pm 0.32^{\mathrm{b}}$ & $5.00 \pm 0.21^{\mathrm{b}}$ & $52.2 \pm 2.1^{\mathrm{c}}$ & $100.8 \pm 4.2^{\mathrm{b}}$ \\
SBM+AS (3:1) & $8.11 \pm 0.32^{\mathrm{b}}$ & $5.22 \pm 0.21^{\mathrm{b}}$ & $56.8 \pm 2.1^{\mathrm{b}}$ & $109.6 \pm 4.1^{\mathrm{b}}$ \\
SBM+AS (1:3) & $6.15 \pm 0.32^{\mathrm{c}}$ & $4.04 \pm 0.21^{\mathrm{d}}$ & $42.9 \pm 2.1^{\mathrm{d}}$ & $82.8 \pm 4.3^{\mathrm{c}}$ \\
\hline
\end{tabular}

Means within a column bearing different superscripts differ $(P<0.05)$

NE: Net energy (MJ/kgDM); ME: metabolizable energy (MJ/kgDM); OMD: organic matter degradation (\%); MP: microbial protein ( $\mathrm{g} / \mathrm{kg}$ DOM), SE: standard error.

The digestibility of measured organic matter is closely correlated with that predicted from gas production and the crude protein and ash contents of feeds. Therefore, the method can be used to predict the extent of digestion for various feeds. The predicted ME and NE which was calculated from gas production after $24 \mathrm{~h}$ incubation were reduced when SBM was treated by heating (autoclaving and roasting) or mixed with A. saligna leaves (Table 3). The values of MP were ranged between 125.4 to 82.8 $\mathrm{g} / \mathrm{kg}$ OMD for SBM and SBM plus AC (1:3), respectively. These results are in agreement with the results of (Czerkawski, 1986) who found that a highly significant correlation between MP syntheses was predicted from OMD in the rumen and that predicted from VFA production. The decrease in DOM, ME and NE in which diets was probably due to increased Maillard products which also decreased rumen degradability and formation of complexes between tannins and dietary proteins and carbohydrates, as well as reduced rumen microbial proteolytic, ureolytic and cellulolytic enzyme activities, general fermentative activities and cell multiplication (Makkar et al., 1988 and Muhammed et al., 1994).

The mean values of true and apparent dry matter and organic matter degradation at 24 and $96 \mathrm{~h}$ incubation in vitro for untreated, treated SBM and mixed SBM with A.saligna leaves in are given in Table (4). The results showed that treating SBM by autoclaving decreased $(\mathrm{P}<0.05)$ the degradation of dry and organic matter (true or apparent) while, the roasting or ethanol treatment did not affect $(\mathrm{P}>0.05)$ degradation of either truly or apparently. Combining SBM with AS leaves decreased $(\mathrm{P}<0.05)$ the dry and organic matter degradation (true and apparent) compared to untreated SBM except the true degradation of dry matter of SBM+AS (3:1) except TDDM of SBM+AS (3:1). The lowest degradation values were observed with SBM+AS (1:3).

Table (4). Least square means $( \pm \mathrm{SE})$ of dry and organic matter degradation (truly and apparently) for untreated and treated SBM and mixed SBM with Acacia saligna leaves.

\begin{tabular}{lcccc}
\hline & \multicolumn{2}{c}{ Degradation at 24 h } & \multicolumn{2}{c}{ Degradation at 96 $\mathrm{h}$} \\
\hline Item & TDDM & TDOM & ADDM & ADOM \\
\hline SBM & $96.1 \pm 3.0^{\mathrm{a}}$ & $94.8 \pm 3.4^{\mathrm{a}}$ & $85.6 \pm 4.0^{\mathrm{a}}$ & $82.5 \pm 4.2^{\mathrm{ab}}$ \\
Ethanol-treated SBM & $95.6 \pm 3.7^{\mathrm{a}}$ & $92.0 \pm 2.8^{\mathrm{ab}}$ & $92.9 \pm 4.0^{\mathrm{a}}$ & $91.8 \pm 3.6^{\mathrm{a}}$ \\
Roasting SBM & $94.9 \pm 4.6^{\mathrm{a}}$ & $93.5 \pm 2.8^{\mathrm{ab}}$ & $95.1 \pm 3.6^{\mathrm{a}}$ & $93.0 \pm 3.6^{\mathrm{a}}$ \\
Autoclaving SBM & $82.6 \pm 3.2^{\mathrm{b}}$ & $78.1 \pm 2.4^{\mathrm{c}}$ & $85.6 \pm 3.6^{\mathrm{a}}$ & $83.3 \pm 3.6^{\mathrm{ab}}$ \\
SBM+AS (1:1) & $74.9 \pm 2.6^{\mathrm{c}}$ & $73.7 \pm 2.4^{\mathrm{c}}$ & $74.4 \pm 3.6^{\mathrm{c}}$ & $69.6 \pm 2.5^{\mathrm{c}}$ \\
SBM+AS (3:1) & $87.6 \pm 3.5^{\mathrm{a}}$ & $86.0 \pm 2.9^{\mathrm{b}}$ & $82.9 \pm 3.6^{\mathrm{b}}$ & $82.0 \pm 3.6^{\mathrm{ab}}$ \\
SBM+AS (1:3) & $63.4 \pm 2.6^{\mathrm{d}}$ & $62.1 \pm 2.4^{\mathrm{d}}$ & $62.1 \pm 2.7^{\mathrm{d}}$ & $60.9 \pm 2.4^{\mathrm{d}}$ \\
\hline
\end{tabular}

Means within a column bearing different superscripts differ $(P<0.05)$

SBM: Soybean meal, AS: Acacia saligna, TDDM: truly digested dry matter, TDOM: truly digested organic matter, ADDM: Apparently digested dry matter, ADOM: Apparently digested organic matter, SE: standards error.

Ammonia-N concentration $\left(\mathrm{NH}_{3}-\mathrm{N}\right)$ for the untreated-, treated SBM and mixed SBM with AS leaves in different proportions incubated in vitro for $24 \mathrm{hr}$ are presented in Figure (2). There were significant differences among substrates in the $\mathrm{NH}_{3}-\mathrm{N}$ concentration. The highest mean value of $\mathrm{NH}_{3}-\mathrm{N}$ concentration was obtained with untreated SBM. The lowest mean value of $\mathrm{NH}_{3}-\mathrm{N}$ concentration was 
obtained with autoclaving SBMfollowed by SBM+AS (1:3), ethanol-treated SBM and roasted SBM, respectively.

The concentrations of $\mathrm{NH}_{3}-\mathrm{N}$ were significantly $(\mathrm{P}<0.05)$ decreased in $\mathrm{SBM}$ treated by heating or mixed with Acacia saligna leaves (Figure 2). In agreement, other researchers has shown that ruminants fed diets containing soybean or cottonseed meal (autoclaved at $121^{\circ} \mathrm{C}$ for 45 and 90 min; Sherrod and Tillman 1962), extruded whole soybeans $\left(155^{\circ} \mathrm{C}\right.$; Block et al., 1981), roasted SBM (115, 130, or $145^{\circ} \mathrm{C}$; Pleggeet al., 1985) or mixed with Acacia saligna leaves (Ben Salem et al., 2005) had a lower ruminal $\mathrm{NH}_{3}-\mathrm{N}$ concentration than ruminants fed a non-heated control. Contradictory, with the present results, Tice et al., (1993) fed cows diets containing heat-treated soybeans (whole soybeans extruded at 132 and $149^{\circ} \mathrm{C}$, or roasted to $143^{\circ} \mathrm{C}$ and steeped for $30 \mathrm{~min}$, respectively) with no decline in ruminal $\mathrm{NH}_{3}-\mathrm{N}$ compared to cows fed whole raw soybeans. The studies of Wallace et al. (1981) and Newboldet al. (1990) have concluded that the lower ammonia concentrations were mainly due to reduced proteolysis, degradation of peptides and deamination of amino acids in the rumen.

The volatile fatty acids (VFA) for the untreated, treated SBM and mixed SBM with A.salignaleaves by different proportions incubated in vitro for $24 \mathrm{~h}$ is shown in Figure (3). The highest mean values for VFA concentrations were obtained with SBM+AS (3:1)and SBM treated with ethanol followed by SBM plus A. saligna leaves (1:3). The lowest mean value of VFA concentration was obtained by autoclaving SBM or roasting SBM.The concentrations of VFA were significantly $(\mathrm{P}<0.05)$ decreased when SBM treated by heating or when mixed with A. saligna 50\% SBM plus 50\% A. saligna (Figure 3 ).

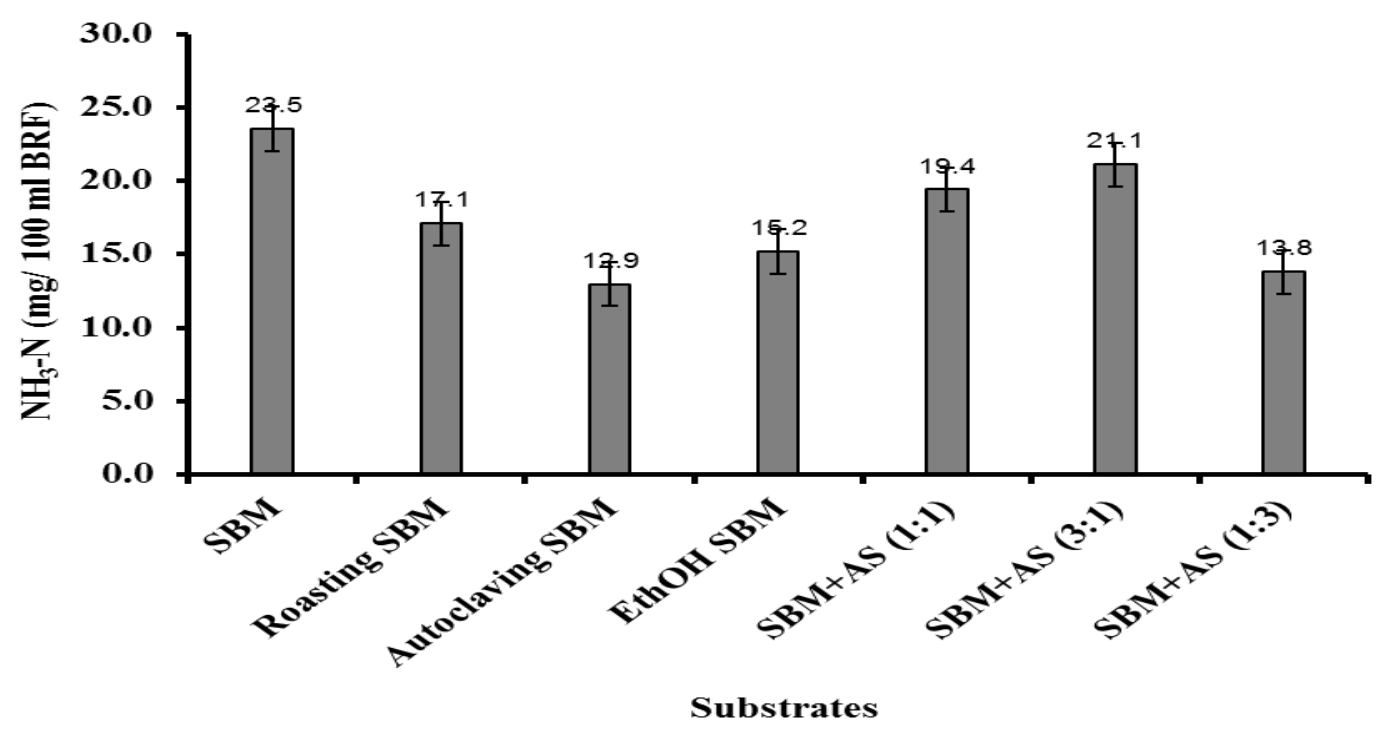

Figure (2). Ammonia-N concentration $\left(\mathrm{NH}_{3}-\mathrm{N}\right)$ for untreated, treated $\mathrm{SBM}$ and mixed SBM with Acacia saligna leaves (AS) by various proportions incubated in vitro for $24 \mathrm{~h}$.

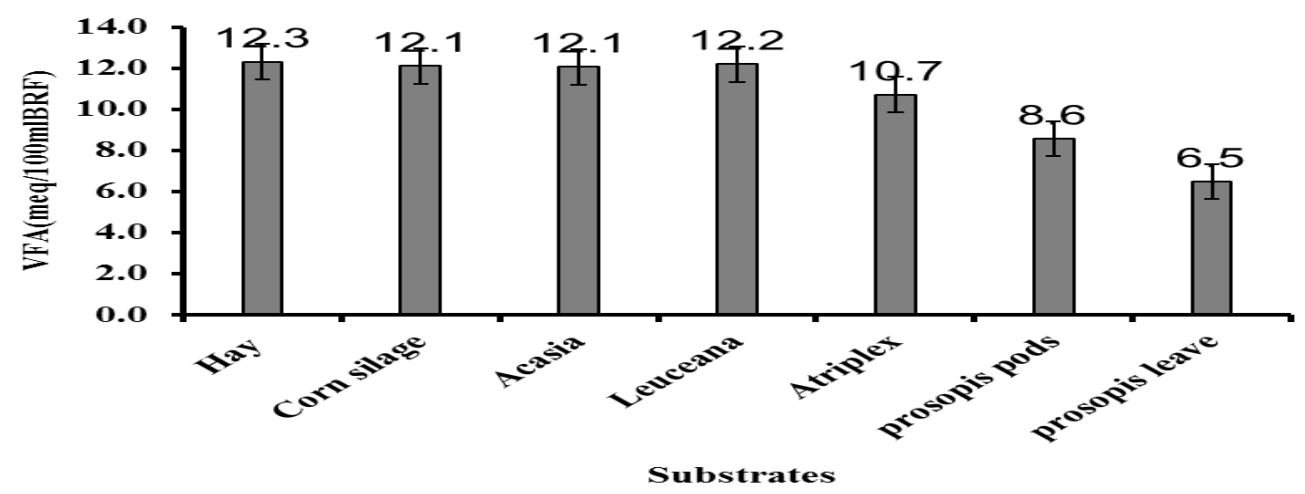

Figure (3). Volatile fatty acids (VFA) concentration for untreated, treated SBM and mixed SBM with Acacia saligna (AS) leaves by various proportions incubated in vitro for $24 \mathrm{~h}$. 
Gas production is an indirect measure of substrate degradation, and is a good predictor for the production of VFA, which is positively related to microbial mass production. The lack of consensus among experiments may be due to differences in the level of heat treatment applied to the oilseeds and meal or to the quantity of soluble $\mathrm{N}$ provided by the non-oilseed portion of the diet. Getachewet al. (1998) stated that in heating, free amino-groups (mainly the epsilon amino-group of lysine) react with other groups to form enzyme-resistant, interand intra-molecular bonds, thereby reducing the solubility and digestibility of the protein.

The mean values of ruminal and intestinal protein degradation using the three step in situ/ in vitro procedure for the untreated, treated SBM and mixed SBM with A.salignaleaves in are presented in Table (5). The RDP content varied from 33.6\% inautoclaving SBMto 62.4\% in SBM+AS (3:1).The RUP differed significantly among feedstuffs. The highest value forRUP was observed in autoclaving SBM but the lowest value observed in SBM+AS (3:1).The IPD content was highest inautoclaving SBM and lowest in $\mathrm{SBM}+\mathrm{AS}(1: 1)$.

Table (5). Least square means ( \pm SE) in situ/ in vitro values of rumen degradable protein, rumen undegradable protein and intestinal protein digestion for treated and untreated SBM using the three step procedure.

\begin{tabular}{lccc}
\hline Item & RDP\% & RUP\% & IPD\% \\
\hline SBM & $52.9 \pm 8.8^{\mathrm{b}}$ & $47.1 \pm 8.8^{\mathrm{c}}$ & $61.1 \pm 7.3^{\mathrm{b}}$ \\
Ethanol- treated SBM & $43.5 \pm 7.2^{\mathrm{c}}$ & $56.5 \pm 7.2^{\mathrm{b}}$ & $52.5 \pm 7.3^{\mathrm{c}}$ \\
Roasting SBM & $54.6 \pm 7.2^{\mathrm{b}}$ & $45.4 \pm 7.2^{\mathrm{c}}$ & $62.5 \pm 6.4^{\mathrm{a}}$ \\
Autoclaving SBM & $33.6 \pm 7.2^{\mathrm{d}}$ & $66.4 \pm 7.2^{\mathrm{a}}$ & $70.3 \pm 7.3^{\mathrm{d}}$ \\
SBM+AC (1:1) & $58.9 \pm 7.2^{\mathrm{ab}}$ & $41.1 \pm 7.2^{\mathrm{cd}}$ & $48.5 \pm 7.3^{\mathrm{a}}$ \\
SBM+AC (3:1) & $62.4 \pm 7.2^{\mathrm{a}}$ & $37.6 \pm 7.2^{\mathrm{d}}$ & $54.7 \pm 7.3^{\mathrm{c}}$ \\
SBM+AC (1:3) & $45.7 \pm 4.4^{\mathrm{c}}$ & $54.3 \pm 4.4^{\mathrm{b}}$ & $51.5 \pm 4.5^{\mathrm{c}}$ \\
\hline
\end{tabular}

Means within a column bearing different superscripts differ $(P<0.05)$

RDP: Rumen degradable protein, RUP: Rumen undegradable protein, IPD: Intestinal protein digestion, SE: standard error.

Lynch et al. (1987) noted that ethanol treatments appeared to be superior to dry heat treatments, because they altered ruminal degradability of SBM protein without reducing its intestinal digestibility.Sadeghi and Shawrang, (2007) found that treatment of SBM with $600 \mathrm{ml} / \mathrm{l}$ ethanol solution was optimal and had the highest potential for increasing RUP of SBM, making higher quality dietary protein available to the ruminant. Observed intestinal digestibility of $\mathrm{CP}$ reaching the duodenum were low, probably due to the presence of tannins, and the high proportion of acid detergent insoluble nitrogen (ADIN) which is not easily digested by intestinal enzymes.

The three-step procedure has been developed to estimate intestinal digestion of ruminalundegraded feed protein in ruminants (Calsamiglia and Stern, 1995) as an alternative to using animals with cannulae in the duodenum and ileum. Stern et al. (1997) compared results of the three-step procedure with in vivo intestinal protein digestion and found a high correlation $\left(r^{2}=0.91\right)$. They concluded that the in vitro method provides an excellent estimate of in situ mobile bag protein degradability and is sensitive to the effects of heat treatment. Mixing A. saligna leaves with SBM decreased ruminal $\mathrm{NH}_{3}-\mathrm{N}$ and in situ degradation of SBM. These findings suggest that Acacia tannins impaired wastage of dietary proteins, mainly from SBM, through microbial degradation in the rumen.

\section{CONCLUSION}

It is concluded that autoclaving SBM, ethanol- treated SBM and mixing SBM with Acacia leaves (1:3) could be used advantageously to reduce RDP, and increase the bypass protein but the autoclaving SBM showed the best treatment on improving the intestinal protein digestion of SBM. 


\section{Attia et al.}

\section{REFERENCES}

AOAC.(1995). Official methods of analysis (16 ${ }^{\text {th }}$ Ed.). Association of Official Analytical Chemists, Arlington, VA, USA.

Ben Salem, H., H.P.S., Makkar, A., Nefzaui, L., Hassayounand S., Abidi.(2005). Benefit from the association of small amounts of tannin-rich shrub foliage (Acacia cyanophyllaLindl.) with soya bean meal given as supplements to Barbarine sheep fed on oaten hay. Anim. Feed Sci. Technol., 122:173186.

Block, E., L.D., Muller, L.C., Griel andD.L., Ganvood.(1981). Brown midrib-3 corn silage and heat extruded soybeans for early lactating dairy cows. J. Dairy Sci., 64:1813.

Broderick, G.A. andW.M., Craig.(1980). Effect of heat treatment on ruminal degradation and escape, and intestinal digestibility of cotton seed meal protein. J. Nutri., 110: 2381-2388.

Calsamiglia, S. and M.D., Stern.(1995). A three-step in vitro procedure for estimating intestinal digestion of protein in ruminants. J. Anim. Sci., 73: 1459-1465.

Cone, J.W., A.H., Van Gelder, A.A., Mathijssen-Kamman andV.A., Hindle.(2006). Post-ruminal digestibility of crude protein from grass and grass silages in cows. Anim. Feed Sci. Technol., 128:4252 .

Corley, R.N., A., Woldeghebriel, M.M., Corley and M.R., Murphy.(1999). Effect of ethanol concentration and application period of soya bean meal on the kinetics of ruminal digestion. Anim. Feed Sci. Technol., 79: 247-254.

Czerkawski, J. W. (1986). An introduction to Rumen Studies, Pergamon Press, Oxford.

DaneshMesgaran, M. and M.D., Stern.(2005). Ruminal and post ruminal protein disappearance of various feeds originating from Iranian plant cultivar determined by the in situ mobile bag technique and alternative methods. Anim. Feed Sci. Technol., 118:31-46.

El-Waziry, A.M., M E.A., Nasser andS.M.A., Sallam.(2005). Processing Methods of soybean Meal: 1Effect of Roasting and Tannic acid Treated-soybean Meal on Gas Production and Rumen Fermentation in vitro. J. Appl. Sci. Res., 1: 313-320.

El-Waziry, A.M., M.E.A., Nasser, S.M.A., Sallam, A.L., Abdallah andI.C.S., Bueno. (2007). Processing Methods of soybean Meal: 2-Effect of Autocalving and Queberacho Tannin Treated-soybean Meal on Gas Production and Rumen Fermentation in vitro. J. Appl. Sci. Res., 3: 17-24.

Frutos, P., G., Hervas, F.J., Giraldez, M., Fernandez andA.R., Mantecon.(2000). Digestive utilization of quebracho treated soyabean meals in sheep. J. Agric. Sci. Camb., 134: 101-108.

Fukushima, D. (1969). Internal structure of $7 \mathrm{~S}$ and $11 \mathrm{~S}$ globulins molecules of soy bean proteins. Cereal Chem., 45: 203-224.

Getachew, G., M., Blummel, H.P.S., Makkar andK., Becker.(1998). In vitro gas measuring techniques for assessment of nutritional quality of feeds: a review. Anim. Feed Sci. Technol., 72: 261281.

Harstad, O.M. andE., PrestlØkken.(2000). Effective rumen degradability and intestinal indigestibility of individual amino acids in solvent-extracted soybean meal (SBM) and xylose-treated SBM (SoyPass) determined in situ. Anim. Feed Sci. Technol., 83: 31- 47.

Horigome, T.R., Kumar and K., Okamoto.(1988). Effect of condensed tannins prepared from leaves of fodder plants on digestive enzymes in vitro and in the intestine of rats. Br. J. Nutr. 60: 275.

Hvelplund, T., F.D., Hovell, E.R., Ørskov and D.J.,Kyle.(1994). True intestinal digestibility of protein estimated with sheep on intra-gastric infusion and with the mobile nylon bag technique. Proc. Soc. Nutr. Physiol. 3: 64

Konishi, C., T., Matsui, W., Park, H., Yano and F., Yano.(1999). Heat treatment of soybean meal and rapeseed meal suppersses rumen degradation of phytate phosphorus in sheep. Anim. Feed Sci. Techn. 80: 115.

LjØkjel, K., O.M., Harstad andA., Skrede.(2000). Effect of heat treatment of soy bean meal and fish meal on amino acid digestibility in mink and dairy cows. Anim. Feed Sci.Technol. 84: 83.

Lynch, G.L., L.L., Berger, Jr., G.C., Fahey.(1987). Effects of ethanol, heat, and lipid treatment of soybean meal on nitrogen utilization by ruminants. J. Dairy Sci., 70: 90-97. 
Makkar, H.P.S. (2003). Effects and fate of tannins in ruminant animals, adaptation to tannins, and strategies to overcome detrimental effects of feeding tannin-rich feeds. Small Rumin. Res., 49: 241256.

Makkar, H.P.S., B., Singh and R.K., Dawra.(1988). Effect of tannin-rich leaves of oak (Quercusincana) on various microbial enzyme activities of the bovine rumen. Br. J. Nutr. 60:287.

Makkar, H. P. S., M., Blummel, N. K., Borowy andK., Becker.(1993). Gravimetric determination of tannins and their correlation with chemical and protein precipitation methods. J. Sci. Food Agric., 61:161-165.

Makkar, H.P.S., M., Blummel andK., Becker.(1995). In vitro effects of and interaction between tannins and saponins and fate of tannins in the rumen. J. Sci. Food Agric., 69: 481-493.

McNiven, M.A., E., Prestlokken, L.T., Mydland andA.W., Mitchell.(2002). Laboratory procedure to determine protein digestibility of heat-treated feedstuffs for dairy cattle. Anim. Feed Sci. Technol., 96: $1-13$.

Menke, K. H., L., Raab, A., Salewski, H., Steingass, D., Fritz andW., Schneider.(1979). The estimation of digestibility and metabolizable energy content of ruminant feedstuffs from the gas production when they are incubated with rumen liquor in vitro. J. Agric. Sci., 193:217-225.

Menke, K.H. andH., Steingass.(1988). Estimation of the energetic feed value obtained from chemical analysis and gas production using rumen fluid. Anim. Res. Dev., 28: 7-55.

Mertens, D.R. (2002). Gravimetric determination of amylase-treated neutral detergent fibre in feed with refluxing beakers or crucibles: collaborative study. J. AOAC. Int. 85: 1217.

Min, B.R., T.N., Barry, G.T., Attwood andW.C., McNabb.(2003). The effect of condensed tannins on the nutrition and health of ruminants fed fresh temperate forages: a review. Anim. Feed Sci. Technol., 106: 3-19.

Mir, Z., G.K., Macleod, J.G., Buchanan-Smith, D.G., Gryeve andW.L., Grovum.(1984). Methods for protecting soybean and canola proteins from degradation in the rumen. Can. J. Anim. Sci., 64: 853865.

Muhammed, S., C.S., Stewartand T., Acamovic.(1994). Effects of tannic acid on cellulose degradation, adhesion and enzymic activity of rumen microorganisms. Proc. Sot. Nutr. Physiol. 3: 174.

Murray, R.K., D.K., Granner, P.A., Mayes andV.W.,Rodwell.(2003). Harper's Biochemistry, 26th ed. McGraw-Hill, New York, NY, USA.

Nakamura, T., T.J., Klopfenstein, D.J., Gibb andR.A., Britton.(1994). Growth efficiency and digestibility of heated protein feed to growing ruminants. J. Anim. Sci., 72: 774-782.

Newbold, C.J., R.J., Wallace andN., Mckain.(1990). Effects of the ionophoretetronasin on nitrogen metabolism by ruminal microorganisms in vitro. J. Anim. Sc. 68: 1103.

Nowak, W., S., Michalak andS., Wylgala.(2005).Insitu evaluation of ruminal degradability and intestinal digestibility of extruded soybeans.Czech J.Anim. Sci., 50, (6): 281-287.

Onodera R. andC.J., Henderson.(1980).Growth factors of bacterial origin for the culture of the rumen oligotrich protozoon, Entodiniumcaudatum. J. Appl. Bacter., 48: 125-134.

Ørskov, E.R. andI., McDonald.(1979). The estimation of protein degradability in the rumen from incubation measurements weighted according to rate of passage. J. Agric. Sci., 92:499-503.

Ørskov, E.R., G.W., Reid andM., Kay.(1988). Prediction of intake by cattle from degradation characteristics of roughages. Anim. Prod., 46: 29-34.

Plegge, S.D., L.L., Berger andG.C., Fahey.(1985). Effect of roasting temperature on the proportion of soybean meal nitrogen escaping degradation in the rumen.J.Anim. Sci., 61: 1211-1218.

Preston, T.R. (1995). Biological and chemical analytical methods. In: Preston, T.R. Tropical animal feeding: a manual for research workers. Rome:FAO, 1995. chap.9, p.191-264.

Robinson, P.H., G.R., Khorasani andJ.J., Kennelly.(1994). Forestomach and whole tract digestion in lactating dairy cows fed canola meal treated with variable levels of acetic acid. J. Dairy Sci., 77: 552559.

Sadeghi, A.A. andP., Shawrang.(2007). Effect of ethanol concentration on the kinetics of ruminal degradation of soybean meal .Anim. Feed Sci. Technol. 136:137-145.

SAS.( 2002). Statistical Analysis System, Version 9.1. SAS Institute, Cary, NC, USA. 
Sherrod, L.B. andA.D., Tillman.(1962). Effects of varying the processing temperatures upon the nutritive values for sheep of solvent-extracted soybean and cottonseed meals. J. Aim. Sci. 21:901.

Soliva, C. R.,T., Takahashi andM.,Kreuzer.(2005).The influence of head space and inculum dilution on in vitroruminal methane measurement. International Conference on Greenhouse Gases and Animal Agriculture.

Steel, R.G.D. andJ.H., Torrie.(1980). Principales and procedures of statistics.Abiometrical approach. Second edition, Mac Graw-Hill Com.

Stern, M.D., A., Bach andS., Calsamiglia.(1997). Alternative techniques for measuring nutrient digestion in ruminants. J. Anim . Sci., 75: 2256-2276.

Taha, F.S. andS.S., Mohamed.(2004). Effect of different denaturating methods on lipid-protein complex formation.Lebensm. Wiss. Technol., 37: 99-104.

Tejido, M.L., M.J., Ranilla andM.D., Carro.(2002). In vitro digestibility of forages as influenced by source of inoculum (sheep rumen versus Rusitec fermenters) and diet of the donor sheep. Anim. Feed Sci. Technol., 97:41-51.

Tice, E.M., M.L., Eastridge andJ.L., Firkins.(1993). Raw soybeans and roasted soybeans of different particle sizes. 1. Digestibility and utilization by lactating cows. J. Dairy Sci. 76224.

Titgemeyer, E.C. andJ.E., Shirley.(1997). Effect of processed grain sorghum and expeller soybean meal on performance of lactating cows.J. Dairy Sci. 80: 714.

Van Gelder, M. H., M.A.M., Rodrigues, J.L., De Boever, H., Den Hartigh, C., Rymer, M., Van Oostrum, R., Van Kaathoven andJ.W., Cone.(2005). Ranking of in vitrofermentability of 20 feedstuffs with an automated production technique: Results of a ring test. Anim. Feed Sci. Technol. 123-124: 243-253.

Van Soest, P.J. (1994). Nutritional Ecology of Ruminants, 2nd edn. Cornell University Press, p. 476.

Waghorn, G.C. andW.T., Jones.(1989). Bloat in cattle; XLVI. Potential of dock (Rumexobtusifolius) as an antibloat agent in cattle. N.Z.J. Agric. Res.32: 227.

Wallace, R.J., J.W., Czerkawski andG., Breckenridge.(1981). Effect of monensin on the fermentation of basal rations in the rumen simulation technique (Rusitec). Br. J. Nutr. 114: 101.

Warner, A.C.I. (1964). Production of volatile fatty acids in the rumen. Methods of measurements. Nutr. Abs. Rev. 34: 339.

الهضم المعملى للبروتين فى الكرش والأمعاء لكسب فول الصويا غير المعامل والمعامل

مروة فايز عبد الخالق عطيه، محمد عماد عبد الوهاب ناصر ، خالد عبد السلام الثاذلى، صبحى عحم عبد الله سلام

قسم الإنتاج الحيوانى والسكى ، كلية الزراعة، جامعة الإسكندرية ، الإسكندرية ، مصر.

أجريت هذه التجربة لتقييم خصائص تخمرات الكرش و هضم البروتين فى الكرش و الأمعاء لكسب فول الصويا غير المعامل و المعامل

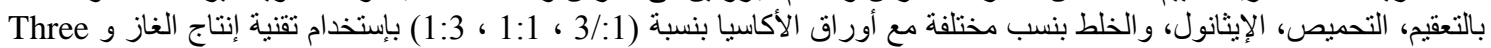
step in situ / in vitro procedure

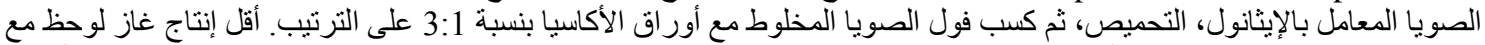

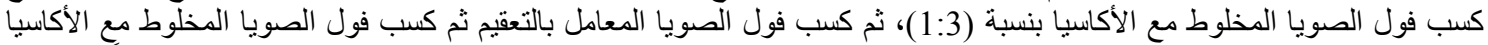

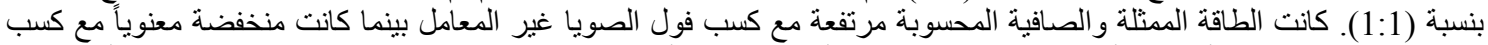

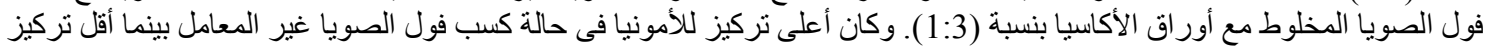

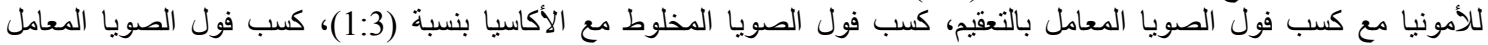

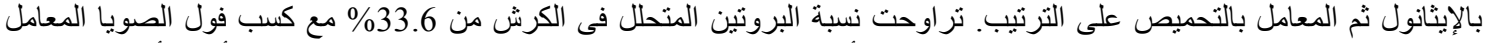

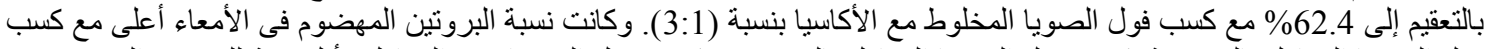

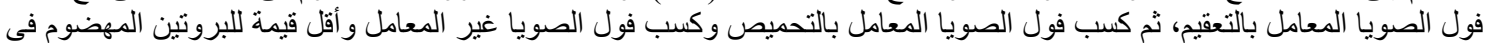

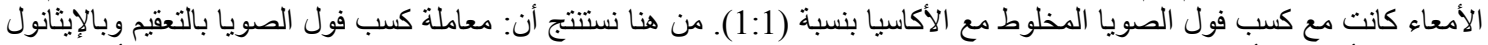

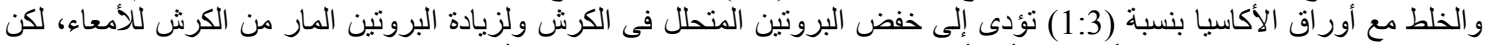
معاملة كسب فول الصويا بالتعقيم أوضحت أنها أفضل معاملة لتحسين هضم البرونين البروتين في الأمعاء. 